\title{
Physical Exercise and Weight Loss for Hip and Knee Osteoarthritis in Very Old Patients: A Systematic Review of the Literature
}

\author{
Jean-Laurent Le Quintrec ${ }^{1}$, Bernard Verlhac ${ }^{2}$, Christian Cadet $^{3}$, Philippe Bréville ${ }^{4}$, \\ Jean M. Vetel ${ }^{5}$, Jean B. Gauvain ${ }^{6}$, Claude Jeandel ${ }^{7}$, Emmanuel Maheu, ${ }^{*}$, \\ and the Geriatrics and Rheumatology Association (AGRHUM)
}

\author{
${ }^{I}$ Service de Médecine Gériatrique 3 [Department of Geriatric Medicine 3], Hôpital Sainte-Périne (A.P-H.P), Paris, \\ France \\ ${ }^{2}$ Pôle Vieillissement, réadaptation et Accompagnement [Centre for the Aged, Rehabilitation and Support], Hôpital Paul \\ Brousse (A.P-H.P) Villejuif, France \\ ${ }^{3}$ Medical Office, Paris, France \\ ${ }^{4}$ Service de Rhumatologie [Department of Rheumatology], Groupe Hospitalier Paris Saint Joseph, Paris, France \\ ${ }^{5}$ Centre Hospitalier, Le Mans, France \\ ${ }^{6}$ Centre de Médecine Interne Gériatrique [Centre for Geriatric Internal Medicine], Centre Hospitalier régional, \\ Orléans, France \\ ${ }^{7}$ Service de Médecine interne et Gériatrie [Department of Internal and Geriatric Medicine], Montpellier, France \\ ${ }^{8}$ Service de Rhumatologie, Rheumatology Department, Medical Office / Hôpital Saint Antoine -A.P-H.P, Paris, France
}

\begin{abstract}
Background: Rheumatologic and geriatric scholarly organisations recommendations for the management of hip and knee osteoarthritis, which emphasise the usefulness of non-pharmacological therapies, are not scaled according to patient's age and physical condition. We conducted a systematic review of clinical trials on exercise and weight loss in hip and knee osteoarthritis in very old patients.

Methods: Electronic search in MEDLINE, EMBASE, PASCAL database, systematic search of the Cochrane Reviews, manual search in guidelines, meta-analyses and identified relevant articles.

Results: We identified 83 trials, with only 2 on patients aged $\geq 75$ years; we therefore lowered the mean age threshold to 70 years and found 15 trials, mainly performed in knee osteoarthritis and outpatients.

Physical exercise (8 trials): was effective on pain and function (4 controlled trials), with a persistent effect only in case of self-rehabilitation.

Aquatic exercise (5 trials): was as effective as land-based exercise.

Weight loss (2 trials): only patients under diet + exercise had significant improvement on symptoms.

Conclusion: Our systematic review confirms that international recommendations on exercise for knee osteoarthritis also apply to subjects aged 70-80 years. Long-term effectiveness requires a maintenance strategy. Specific trials on very old patients with various comorbidities are mandatory, given that these subjects are more exposed to drug-related iatrogenesis.
\end{abstract}

Keywords: Hip osteoarthritis, knee, physical exercise, systematic review, very old, weight loss.

\section{INTRODUCTION}

The incidence and prevalence of osteoarthritis (OA) increase with aging of the population, particularly in industrialised countries [1]. Osteoarthritis of the lower limbs can seriously affect subject's independence and thereby influence lifestyle and care in old and very old patients.

*Address correspondence to this author at the Service de rhumatologie APHP Hôpital Saint Antoine F-75012, Paris, France; Tel: +33 6222489 80; E-mail: emaheu@wanadoo.fr
The major rheumatological scholarly organisations (EULAR, OARSI, ACR) have published recommendations on the treatment of knee and hip OA [2-5]: all emphasize the required combination of pharmacological and nonpharmacological measures, including aerobic and resistance exercises, aquatic exercises, and weight loss in overweight or obese subjects. However, these recommendations are based on clinical trials conducted in patients with an average age between 60 and 70 years, therefore very different from very old and/or polypathologic patients, and are not scaled according to patient's age and physical condition. 
The American Geriatrics Society (AGS) published in 2001 recommendations for prescribing physical exercise in old patients [6]. However, they are based on relatively ancient trials and not differentiated according to age or polypathology.

EULAR 2013 recommendations [7], which give detailed guidance for the non-pharmacological management of hip and knee OA, do not take into account the age of patients, nor the feasibility or hazards of exercise and weight loss in old and very old patients.

A group of geriatrician-rheumatologists was formed a few years ago within the French Society of Rheumatology (SFR - Société Française de Rhumatologie): the Geriatrics and Rheumatology Association (AGR - Association Gériatrie et Rhumatologie). More recently a wider working group entitled AGRHUM was formed within the French Society of Geriatrics and Gerontology (SFGG - Société Française de Gériatrie et Gérontologie). These groups decided to take an inventory of existing clinical trials on the treatment of $\mathrm{OA}$ in very old patients. We present here this systematic review of trials on physical exercise and weight loss in hip and knee OA in very old patients ( 75 years and older).

\section{METHODS}

We performed a systematic bibliographical search of the literature looking for clinical trials on non-pharmacological treatment of hip and knee OA in patients aged 75 years and older. The search was focused on physical exercise, aquatic exercise and balneotherapy, and weight loss. Education and information, physiotherapy (hot/cold, laser, ultrasound, percutaneous electrical stimulation), massage, Spa-therapy and acupuncture did not fall within the scope of this research.

The search strategy was as follows:

1. Search in MEDLINE, EMBASE, and PASCAL database for manuscripts published in English, using the following keywords: hip/knee OA; exercise; aquatic exercise; balneotherapy; weight loss; weight reduction. The activated filters were: clinical trials, abstract available, published in the last ten years, age eighty and over. For this last age filter, we initially selected a "sixty five and over" filter: this filter, active as soon as age $\geq 65$ years was quoted in the text, resulted in the case of osteoarthritis, to make no selection for age. This led to use the "eighty and over " filter, which is activated as soon as age $\geq 80$ years was quoted in the text.
2. Study of the Cochrane Reviews: "aquatic exercise for the treatment of knee and hip osteoarthritis", "exercise for osteoarthritis of the hip", "exercise for osteoarthritis of the knee", "home versus center based physical activity programs in older adults", "intensity of exercise for the treatment of osteoarthritis", " balneotherapy for osteoarthritis". In each of these reviews a comprehensive manual search of selected trials and excluded trials was performed.

3. Manual search of references in international guidelines, meta-analyses and systematic reviews.

4. Manual search of references in all relevant articles obtained during the previous steps.

\section{RESULTS}

We identified a total of 83 trials (Table $\mathbf{1}$ ).

Among them, only two concerned subjects aged $\geq 75$ years on average; we therefore decided to lower the mean age for selecting articles to 70 years. This led to a selection of 15 papers and 13 trials [8-22], two being duplicates [8, 9, $14,15]$. The 2 trials on weight loss [23, 24] included patients with a mean age slightly under 70 years: we however, kept them, given the scarcity of trials on weight loss in elderly patients. The methodological quality of these 15 trials, was assessed by the Jadad score [25], with an average score of $3 / 5$.

Heterogeneity of trials did not allow carrying out a metaanalysis.

\section{Physical Exercises}

We identified 8 trials (10 manuscripts: 8-17) which included a total of 764 patients (Table 2).

- All were randomised controlled trials, including 5 with a control group. Five trials were given single-blind assessment. Post-treatment evaluation was performed on 72 to $100 \%$ of included patients. Five trials performed a followup assessment on 50 to $92 \%$ of included patients, within three months to one year after inclusion.

Six trials were conducted in knee $\mathrm{OA}$ and two in knee and/or hip OA.

Treatments were land-based exercises in 6 trials: these exercises were performed in groups in 4 trials $[8,10,14,16]$, at home in 1 trial [12]; the latest trial studied stationary bike with exercises of different intensities [11]. Another trial tested the involvement of occupational therapists to increase daily physical activity [17]. The last trial studied a

Table 1. Trials identified by the Bibliographical Search.

\begin{tabular}{|c|c|c|c|}
\hline & Total Number of Trials & $\begin{array}{c}\text { Number of Trials with Average Age } \\
\geq \mathbf{7 5} \text { years }\end{array}$ & $\begin{array}{c}\text { Number of Trials with Average Age } \\
\geq \mathbf{7 0} \text { years }\end{array}$ \\
\hline \hline Exercise & 50 & 1 & $\mathbf{8}$ \\
\hline Aquatic Exercise & 16 & 1 & $\mathbf{5}$ \\
Balneotherapy & 9 & 0 & 0 \\
\hline Weight Loss & 8 & 0 & $\mathbf{2}$ \\
\hline
\end{tabular}


Table 2. Randomised controlled trials on physical exercise.

\begin{tabular}{|c|c|c|c|c|c|c|c|c|c|c|}
\hline & $\mathbf{N}$ & $\begin{array}{c}\text { Average } \\
\text { Age } \\
\pm \text { SD }\end{array}$ & $\begin{array}{c}\% \\
\text { Women }\end{array}$ & Lifestyle & $\begin{array}{c}\text { Affected } \\
\text { Joint }\end{array}$ & $\begin{array}{c}\text { Exclusion } \\
\text { Criteria }\end{array}$ & $\begin{array}{c}\text { Blinded } \\
\text { Assessment }\end{array}$ & Patients Groups & Assessment & Results \\
\hline $\begin{array}{c}\text { Kovar (1992) [8] } \\
\text { Sullivan (1998) [9] }\end{array}$ & $\begin{array}{c}102 \\
52\end{array}$ & $70.4 \pm 9.1$ & $84 \%$ & independent & knee & $\begin{array}{l}\text {-Dementia } \\
\text {-Pathologies } \\
\text { CI exercise }\end{array}$ & No & $\begin{array}{c}\text {-Control (phone calls) } \\
\text {-exercise }+ \\
\text { education }\end{array}$ & $\begin{array}{l}8 \text { weeks } \\
1 \text { year }\end{array}$ & $\begin{array}{c}\downarrow \text { pain* } \\
\uparrow \text { function* } \\
\downarrow \text { pain } \\
\end{array}$ \\
\hline Rogind (1998) [10] & 25 & $71.2 \pm 7.4$ & $91 \%$ & independent & $\begin{array}{l}\text { Knee } \\
\text { (severe) }\end{array}$ & $\begin{array}{l}\text {-Dementia } \\
\text {-Pathologies } \\
\text { CI exercice } \\
\text {-Hip OA }\end{array}$ & Yes & $\begin{array}{c}\text {-Control (non- } \\
\text { training) } \\
\text {-Exercise } \\
\text { +self-rehabilitation }\end{array}$ & $\begin{array}{l}3 \text { months } \\
1 \text { year }\end{array}$ & $\begin{array}{c}\downarrow \text { pain* } \\
\uparrow \text { function* } \\
\downarrow \text { pain* } \\
\uparrow \text { function* }\end{array}$ \\
\hline $\begin{array}{l}\text { Kline Mangione } \\
\text { (1999) [11] }\end{array}$ & 54 & $71.0 \pm 6.9$ & $67 \%$ & independent & knee & $\begin{array}{l}\text { Pathologies } \\
\text { CI exercise }\end{array}$ & No & $\begin{array}{l}\text {-Bike high intensity } \\
\text {-Bike low intensity }\end{array}$ & 10 weeks & $\begin{array}{c}\downarrow \text { pain }^{\circ} \\
\uparrow \text { function }^{\circ}\end{array}$ \\
\hline Petrella (2000) [12] & 179 & $74.0 \pm 6.0$ & $57.5 \%$ & independent & knee & $\begin{array}{l}\text {-Dependency } \\
\text {-pathologies } \\
\text { CI exercise }\end{array}$ & Yes (double) & $\begin{array}{l}\text {-Control (sham } \\
\text { exercise) } \\
\text {-home exercise }\end{array}$ & 8 weeks & $\begin{array}{c}\downarrow \text { pain* } \\
\uparrow \text { function* }\end{array}$ \\
\hline Talbot (2003) [13] & 34 & $70.2 \pm 6.7$ & $76.5 \%$ & independent & knee & $\begin{array}{l}-\mathrm{MMS}<24 \\
\text {-Pathologies } \\
\text { CI exercise }\end{array}$ & No & $\begin{array}{l}\text {-Control (education) } \\
\text {-Podometer }\end{array}$ & $\begin{array}{l}6 \text { months } \\
9 \text { months }\end{array}$ & $\begin{array}{l}\uparrow \text { step count } \\
\text { nothing }\end{array}$ \\
\hline $\begin{array}{l}\text { Hughes (2004) [14] } \\
\text { Hughes (2006) [15] }\end{array}$ & $\begin{array}{l}150 \\
215\end{array}$ & $73.3 \pm 6.7$ & $81 \%$ & independent & $\begin{array}{l}\text { Knee and } \\
\text { hip }\end{array}$ & Dementia & Yes & $\begin{array}{l}\text {-Control (notebook) } \\
\text {-resistance exercise }\end{array}$ & $\begin{array}{l}2 \text { months } \\
1 \text { year }\end{array}$ & $\begin{array}{c}\downarrow \text { pain* } \\
\uparrow \text { function* } \\
\downarrow \text { pain }^{\circ} \\
\uparrow \text { function* }^{*}\end{array}$ \\
\hline $\begin{array}{c}\text { Williamson (2007) } \\
{[16]}\end{array}$ & 181 & $70.0 \pm 8.8$ & $55.5 \%$ & $\begin{array}{c}\text { Not } \\
\text { specified }\end{array}$ & $\begin{array}{l}\text { Knee } \\
\text { (severe) }\end{array}$ & $\begin{array}{l}\text {-Homolateral } \\
\text { Hip OA }\end{array}$ & Yes & $\begin{array}{l}\text {-Control (brochure) } \\
\text {-Acupuncture } \\
\text {-exercise }\end{array}$ & $\begin{array}{l}7 \text { weeks } \\
12 \text { weeks }\end{array}$ & $\begin{array}{c}\uparrow \text { function } \\
\text { (acupuncture)* } \\
\text { nothing }\end{array}$ \\
\hline Murphy (2008) [17] & 54 & $75.3 \pm 7.1$ & $93 \%$ & $\begin{array}{l}\text { Résidences } \\
\text { (4 sites) }\end{array}$ & $\begin{array}{c}\text { K } 67 \% \\
\text { K+H 22\% } \\
\text { H } 11 \%\end{array}$ & Dementia & Yes & $\begin{array}{c}\text { Exercise+OT } \\
\text { Exercise+education }\end{array}$ & 6 weeks & 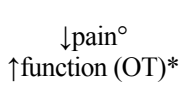 \\
\hline
\end{tabular}

K: knee osteoarthritis; H: hip osteoarthritis; OA: osteoarthritis; CI: contra-indicating; OT: occupational therapy.

${ }^{\circ}$ : significant intragroup difference; *: significant intergroup difference.

programme with a gradual increase in the step count at home, self-monitored by a podometer [13].

- Among the 6 trials on physical exercise, 4 out of the 5 trials with a control group $[8,10,12,14]$ found physical exercise to be effective on pain and function (walking speed and/or distance) and one [16] did not; the last trial, focused on stationary bike [11], found a within-group difference on function. Exercise with occupational therapy was more effective than exercise with education [17]. Podometer selfmonitoring increased walking speed [13]. An increase in aerobic ability [11] and quadriceps strength [10, 13] was recorded in trials which evaluated these criteria. Activities of daily living were also improved in the trial which did evaluate this outcome [8]. Exercises were also effective in advanced OA [10].

Follow up found no evidence of persistence of effect [9, 13], except in cases of scheduled [15] or probable [10] home-based self-rehabilitation.

- There were few side effects: 1 patient had a fall resulting in a hip fracture [8]. Other side effects were minor and did not result in patient dropout. Overall tolerance was good, even in advanced OA $[10,16]$.

\section{Aquatic Exercises}

We identified 5 trials [18-22] which included 457 patients (Table $\mathbf{3}$ ).
- All were randomised controlled trials: all used a blinded assessment and 4 a control group. Post-treatment assessment of patients involved 78.2 to $95.4 \%$ of included patients. Two trials had a follow-up assessment involving 80.5 to $90.8 \%$ of included patients.

Four trials were conducted in hip or knee OA [18-20, 22] and 1 in hip OA [21].

Tested treatments were aquatic or land-based exercises versus control in 2 trials $[18,19]$, aquatic exercises versus land-based exercises in one trial [20], aquatic exercises versus control in one trial [22] and aquatic exercises with or without education in one trial [21].

- The effectiveness of aquatic exercises was demonstrated on pain and function versus controls in 2 trials $[18,19]$ and within group in one trial [20]. One trial with control group [22] failed to show any statistically significant difference favouring aquatic exercise.

Overall, the effectiveness of aquatic exercise was similar to that of land-based exercise. In hip OA, aquatic exercises were only effective if associated with rehabilitation sessions to implement them in land-based activities [21].

Results were broadly persistent after follow-up, which was of short duration (8 to 12 weeks) $[19,20]$. 
Table 3. Randomised controlled trials on aquatic exercise.

\begin{tabular}{|c|c|c|c|c|c|c|c|c|c|c|}
\hline & $\mathbf{N}$ & $\begin{array}{c}\text { Average } \\
\text { Age } \pm \text { SD }\end{array}$ & $\begin{array}{c}\% \\
\text { Women }\end{array}$ & Lifestyle & Affected Joint & $\begin{array}{c}\text { Exclusion } \\
\text { Criteria }\end{array}$ & $\begin{array}{c}\text { Blinded } \\
\text { Assessment }\end{array}$ & Patients Groups & Assessment & Results \\
\hline $\begin{array}{c}\text { Foley } \\
(2003)[18]\end{array}$ & 105 & $70.9 \pm 8.8$ & $49.5 \%$ & independent & \begin{tabular}{|c|}
$\mathrm{K}$ or $\mathrm{H}$ \\
$40 \%$ (awaiting \\
surgery)
\end{tabular} & Dementia & Yes & $\begin{array}{c}\text {-control (C): phone calls } \\
\text {-aquatic ex (A) } \\
\text {-land-based ex (L) }\end{array}$ & 6 weeks & $\begin{array}{c}\downarrow \operatorname{pain}(\mathrm{A})^{\circ} \\
\uparrow \text { function }(\mathrm{A}=\mathrm{L}>\mathrm{C})^{*}\end{array}$ \\
\hline $\begin{array}{c}\text { Fransen } \\
(2007)[19]\end{array}$ & 152 & $70.0 \pm 6.3$ & $74 \%$ & independent & $\mathrm{K}$ and/or $\mathrm{H}$ & $\begin{array}{l}\text { Pathologies } \\
\text { CI exercise }\end{array}$ & Yes & $\begin{array}{c}\text {-control (C) } \\
\text {-aquatic ex (A) } \\
\text {-Taï Chi (T) }\end{array}$ & $\begin{array}{l}12 \text { weeks } \\
24 \text { weeks }\end{array}$ & $\begin{array}{c}\downarrow \text { pain }(\mathrm{A}>\mathrm{T}>\mathrm{C})^{*} \\
\uparrow \text { function }(\mathrm{A}>\mathrm{T}>\mathrm{C})^{*} \\
\text { maintained } \\
\text { (self-rehabilitation) }\end{array}$ \\
\hline $\begin{array}{l}\text { Gill (2009) } \\
{[20]}\end{array}$ & 82 & $70.3 \pm 9.8$ & $62 \%$ & Independent & $\begin{array}{l}\text { K or H } \\
\text { (awaiting } \\
\text { surgery) }\end{array}$ & $\begin{array}{c}\text { Not } \\
\text { specified }\end{array}$ & Yes & $\begin{array}{c}\text {-aquatic ex (A) } \\
\text {-land-based ex (L) }\end{array}$ & $\begin{array}{l}6 \text { weeks } \\
14 \text { weeks }\end{array}$ & $\begin{array}{c}\downarrow \text { pain }(\mathrm{A}=\mathrm{L})^{\circ} \\
\uparrow \text { function }(\mathrm{A}=\mathrm{L})^{\circ} \\
\text { maintained }\end{array}$ \\
\hline $\begin{array}{c}\text { Arnold } \\
(2010)[21]\end{array}$ & 79 & $73.2 \pm 4.8$ & $71 \%$ & independent & $\begin{array}{l}\mathrm{H}+1 \text { fall or } 1 \\
\text { fall risk factor }\end{array}$ & $\begin{array}{c}\text { Not } \\
\text { specified }\end{array}$ & Yes & $\begin{array}{c}\text {-control (C): usual } \\
\text { activities } \\
\text {-aquatic ex+education } \\
\text { (AE) } \\
\text {-aquatic ex (A) }\end{array}$ & 11 weeks & $\begin{array}{c}\uparrow \text { balance }(\mathrm{AE}>\mathrm{C})^{*} \\
\uparrow \text { function }(\mathrm{AE}>\mathrm{A}, \mathrm{C}) *\end{array}$ \\
\hline $\begin{array}{c}\text { Hale }(2012) \\
{[22]}\end{array}$ & 39 & $75.0 \pm 1.3$ & $74 \%$ & independent & $\begin{array}{l}\mathrm{K} \text { and/or } \mathrm{H}+ \\
1 \text { fall risk } \\
\text { factor }\end{array}$ & $\begin{array}{l}\text {-Dementia } \\
\text {-Pathologies } \\
\text { CI exercise }\end{array}$ & Yes & $\begin{array}{l}\text {-control }(\mathrm{C}) \text { : internet } \\
\text { training } \\
\text {-Aquatic ex (A) }\end{array}$ & 12 weeks & $\begin{array}{l}\uparrow \text { balance }(\mathrm{C})^{\circ} \\
\uparrow \text { function }(\mathrm{C})^{\circ}\end{array}$ \\
\hline
\end{tabular}

K: knee osteoarthritis; H: hip osteoarthritis; CI: contra-indicating; ex: exercise; ${ }^{\circ}$ : significant intragroup difference; *: significant intergroup difference.

Tolerance was excellent: some transient pain exacerbations were reported, but did not result in patient dropout $[18,19,21]$.

\section{Weight Loss}

We found 2 trials $[23,24]$ which included 87 and 316 patients, (total 403 patients) (Table 4).

These trials were performed by the same team, but published at a two-year interval.

- Both were randomised controlled trials with singleblind assessment. Post-treatment assessment was performed on 77 to $80 \%$ of included patients. Both trials were conducted in knee OA.

One trial compared the diet and exercise association to a control group [24]. The other compared diet and exercise, diet, or exercise with a control group (4 groups) [23].

- Weight loss reached 3.7 to $8.7 \%$ of baseline weight, and was highest in the diet + exercise group. Only patients under diet + exercise had a significant pain reduction and functional improvement, compared to the control group.

There was no significant side effect.

\section{DISCUSSION}

To our knowledge, this is the first systematic review of the literature on the tolerance and effectiveness of physical exercise and weight loss for hip and knee OA in very old patients, which are first line therapeutic options recommended by all published therapeutic guidelines in OA [2-7].

- Physical exercises were found to be effective on pain and function. These results are highly significant given that such trials are subject to strong methodological constraints: single-blind is sometimes difficult to enforce [8], and low sample sizes frequently limit statistical power, which in additioncould also be reduced by the possible effect of sham treatment in the control group: brochures and educational sessions may encourage controls to increase their activity by themselves, and trips to the centre can provide general stimulation [13]. In the literature, effectiveness of physical exercise in the elderly is considered equivalent to that observed in younger adults [6]. The negative results of the trial by Williamson [16] can be explained by two limitations: subjects included with very advanced osteoarthritis and the low number of sessions, 6 performed at a weekly interval. This trial is the one with the lowest number of sessions, whereas a dose effect has been suspected [12]: in adults, a

Table 4. Randomised controlled trials on weight loss.

\begin{tabular}{|c|c|c|c|c|c|c|c|c|c|c|}
\hline Messier (2004) [23] & 316 & $69.0 \pm 0.8$ & $74 \%$ & independent & Knee & MMS $<24$ & Yes & $\begin{array}{c}\text {-control (education) } \\
\text {-diet+exercise (DE) } \\
\text {-diet (D) } \\
\text {-exercise (E) }\end{array}$ & 18 months & $\begin{array}{c}\downarrow \text { pain }(\mathrm{DE})^{*} \\
\uparrow \text { function } \\
\text { (DE)* }\end{array}$ \\
\hline Miller (2006) [24] & 87 & $69.7 \pm 0.6$ & $64.9 \%$ & independent & Knee & $\begin{array}{l}\text { Pathologies } \\
\text { CI exercise }\end{array}$ & Yes & $\begin{array}{c}\text {-control (education) } \\
\text {-diet+exercise }\end{array}$ & 6 months & $\begin{array}{c}\downarrow \text { pain * } \\
\uparrow \text { function* }\end{array}$ \\
\hline
\end{tabular}

CI: contra-indicating ${ }^{\circ}$ : significant intragroup difference; ${ }^{*}$ : significant intergroup difference. 
Cochrane Review on exercises for knee osteoarthritis [26] concluded that programmes including at least twelve sessions are more effective than those with less.

- Most trials on aquatic exercises found a short-term effectiveness. The population studied in these trials is deemed independent, but some subjects are nevertheless on waiting lists for arthroplasty [18,20], and therefore suffering from advanced osteoarthritis; however aquatic exercises are effective and well tolerated in these patients. The negative results of the Hale's trial [22] could be explained by a lack of power, and a possible positive effect of centre-based computer-training sessions in the control group.

- The small number of trials found on weight loss precludes any formal conclusion. Weight loss alone seems ineffective on pain and function [23]. Diet + exercise combination seemed effective [23, 24], even in case of moderate weight loss (5-8\% of the initial weight).

- The beneficial effect of muscular training on osteoarthritic joint may improves joint stability, and potentially slows down joint degradation $[13,27]$; it also prevents stiffness and articular flessum worsening [28]. Among patients suffering from knee osteoarthritis, isometric quadriceps exercises have been shown to increase hyaluronic acid molecular weight and synovial fluid viscosity [29].

- Whether aerobic or resistance training (anaerobic) should be recommended, is still debated. A meta-analysis in adults $[30,31]$ found resistance exercises effective on shortterm pain, and aerobic exercises effective on long-term function. Resistance exercises have not been enough studied in elderly [32]. Both kind of exercises may be complementary and should be included in rehabilitation programmes for OA patients [14, 30, 31].

- The mechanism of action of aquatic exercises does not seem different from that of land-based exercises. The analgesic effect of hot water may explain short-term effectiveness on pain, and good tolerance of intensive aquatic exercises [20]; immersion decreases the muscular work required for joint mobilisation and allows to take care of patients who do not tolerate land-based exercises [19]; nevertheless it probably reduces the gain of muscle strength obtained [18]; partial immersion also reduces the risk of falls, which is interesting in patients with an unstable equilibrium [22].

- Intensive weight-loss diet reduces pain and improves function in adults with knee osteoarthritis through overall weight loss [33]. It modifies also body composition by reducing body fat mass, but also lean body mass in equivalent proportions to those observed in adults; this decrease in lean body mass does not prevent improvement in function at six months [24] but long-term data are missing.

- Overall, safety was good. Aerobic and resistance exercises used in trials were adapted for old patients and often gradually implemented, as recommended [6]. Weight loss-induced sarcopenia and osteoporosis must be carefully considered before prescribing an intensive and/or prolonged diet in old patients [34], even if intentional weight loss is not associated with increased mortality in old subjects [35].

Land-based exercises should be performed between 1 and 3 times a week; session duration depends on the type of exercise, from 25 minutes on a bike to 90 minutes if associated rehabilitation. The duration of exercises should not exceed 60 minutes per session, and is generally gradual, to improve tolerance, compliance and effectiveness [12].

Centre-based rehabilitation stimulates patients by encouraging travelling and meetings: this may explain improvement observed in some control groups. Nevertheless it requires from patients several trips a week, and is difficult to convert into a home-based maintenance programme. Home-based rehabilitation [12] is more difficult to initiate and to assess for compliance and effectiveness, but its longterm maintenance seems better. A Cochrane Review [36] favoured home-based over centre-based rehabilitation in the elderly, but none of the trials were performed in OA.

Whether centre-based or home-based, the persistence of physical activity remains unsolved in OA patients, regardless of age: maintenance can be improved by implementing "booster sessions" [37], focusing on exercise requiring costless equipment [14], and by a customised strategy of positive reinforcement [30].

- The good safety of aquatic exercises in subjects with advanced OA [18] is of particular interest. However aquatic rehabilitation requires a higher infrastructure and financial investment than land-based rehabilitation. Aquatic exercises are therefore inadequate for patients with dementia or polypathology. In the absence of demonstrated superiority of aquatic rehabilitation, land-based rehabilitation should be the first recommended option [20].

- The only study performed on institutionalised elderly patients does not report long-term results [17]. Institutionalised subjects who benefit from sessions in their institution should have a more sustainable result if a suitable maintenance programme is settled. A recent Cochrane Review [38] on rehabilitation for institutionalised older people analysed 67 trials involving 6,300 patients (average age $83 \pm 8$ years), without focusing on OA. It concluded that rehabilitation modestly but significantly improves independence of residents, and their muscular strength, range of motion and balance, and was well tolerated. This regards only half of the residents, a major cognitive decline being a major contra-indication, but can successfully be practised by residents moving with technical assistance.

- We found 13 trials with an average age $\geq 70$ years, which means the presence of subjects aged between 50 and 70. Collection of each patient' data would have allowed us to select and analyse separately subjects over 75 years: we were not able to access database.

- Few trials were conducted in hip OA. Furthermore, trials including hip and knee OA did not generally stratify analyses according to the joint affected.

- To complete our review, we also searched for ongoing trials on non-pharmacological treatment in hip and knee OA on "ClinicalTrials.gov" website. For land-based exercises, we found fourteen trials, including one described in this review [17]. Of the remaining thirteen trials, only one focused on hip OA; three had a lower age limit above 60 (62, 65 and 70 years). For aquatic exercises, we only found one trial, included in this review [21]. For weight loss, the site reported only the Messier trial [23]. 
This orientation of research toward land-based exercises seems realistic for very old or polypathologic subjects. However 8 of these 13 trials a priori excluded patients suffering from dementia and/or polypathology, and none was performed in an institution.

\section{CONCLUSION}

This systematic review confirms that international recommendations for the non-pharmacological treatment of knee OA also apply to subjects aged 70 - 80 years. Evidence for hip OA is insufficient. The complementary nature of land-based and aquatic exercises, and the need for reinforcement strategies to sustain physical activity must be underscored.

We also confirm the lack of published trials and research projects on the risk/benefit ratio of such interventions in very old and/or polypathologic subjects. Specific trials focused on land-based exercise, particularly in institutionalised subjects are needed. Performing such trials is a major public health challenge in these populations exposed to drug-related iatrogenesis.

Based on this review, our recommendations are to propose to all old patients at least regular land-based exercises sessions, if not painful on moves, in order to improve mobility and muscle strength (2 to 3 times a week, sessions of 20 to 60 minutes according to the type of exercise). Additionally, managing a weight loss in overweight patients might be useful, after ensuring they are not affected by sarcopenia.

\section{AUTHORS CONTRIBUTION}

JL Le Quintrec, B Verlhac and E Maheu take responsibility for conception and design of the study, acquisition and analysis of data, drafting and final version of this article.

C Cadet, P Breville, JM Vetel, JB Gauvain and C Jeandel participated to conception and design of the study, revision and final approval of the article.

\section{CONFLICT OF INTEREST}

The authors confirm that this article content has no conflict of interest.

\section{ACKNOWLEDGEMENTS}

Declared none.

\section{REFERENCES}

[1] Etgen O, Reginster JY. Degenerative musculoskeletal disease. Ann Rheum Dis 2004; 63: 1-3

[2] Jordan KM, Arden NK, Bannwarth B, et al. EULAR recommendations 2003: an evidence based approach to the management of knee osteoarthritis: report of a task force of the standing committee for international clinical studies including therapeutic trials (ESCISIT). Ann Rheum Dis 2003; 62: 1145-55.

[3] Zhang W, Doherty M, Arden N, et al. EULAR evidence based recommendations for the management of hip osteoarthritis: report of a task force of the EULAR standing committee for international clinical studies including therapeutics (ESCISIT). Ann Rheum Dis 2005; 64: 669-81.

[4] Zhang W, Nuki G, Moskowitz RW, et al. OARSI recommendations for the management of hip and knee osteoarthritis Part III: changes in evidence following systematic cumulative update of research published through January 2009 Osteoarthritis Cartilage 2010; 18: 476-99.

[5] Hochberg MC, Altman RD, Toupin April K et al; American College of Rheumatology 2012 recommendations for the use of non-pharmacologic and pharmacologic therapies in osteoarthritis of the hand, hip and knee. Arthritis Care Res 2012; 64: 465-74.

[6] American Geriatrics Society Panel on Exercise and Osteoarthritis. Exercise prescription for older adults with osteoarthritis pain: consensus practice recommendations. JAGS 2001; 49: 808-23.

[7] Fernandes L, Hagen KB, Bjilsma JW, et al. EULAR recommendations for the non-pharmacological core management of hip and knee osteoarthritis. Ann Rheum Dis 2013; 72: 1125-35

[8] Kovar PA, Allegrante JP, MacKenzie R, et al. Supervised fitness walking in patients with osteoarthritis of the knee. Ann Intern Med 1992; 116: 529-34.

[9] Sullivan T, Allegrante JP, Peterson MGE, et al. One-year followup of patients with osteoarthritis of the knee who participated in a program of supervised fitness walking and supportive patient education. Arthritis Care Res 1998; 11: 228-33.

[10] Rogind H, Bibow-Nielsen B, Jensen B, et al. The effects of a physical training program on patients with osteoarthritis of the knees. Arch Phys Med Rehabil 1998; 79: 1421-27.

[11] Kline Mangione K, McCully K, Gloviak A, et al. The effects of high-intensity and low-intensity cycle ergometry in older adults with knee osteoarthritis. J Gerontol Med Sciences 1999; 54A: M184-90.

[12] Petrella RJ and Bartha C. Home based exercise therapy for older patients with knee osteoarthritis: a randomized clinical trial. J Rheumatol 2000; 27: 2215-21.

[13] Talbot LA, Gaines JM, Huynh Tu N, Metter EJ. A home-based pedometer-driven walking program to increase physical activity in older adults with osteoarthritis: a preliminary study. JAGS 2003; 51: 387-92.

[14] Hughes SL, Seymour RB, Campbell R, et al. Impact of the fit and strong intervention on older adults with osteoarthritis. Gerontologist 2004; 44: 217-28.

[15] Hughes SL, Seymour RB, Campbell R, et al. Long-term impact of Fit and Strong ! on older adults with osteoarthritis. Gerontologist 2006; 46: 801-14.

[16] Williamson L, Wyatt MR, Yein K, Melton JTK. Severe knee osteoarthritis: a randomized controlled trial of acupuncture, physiotherapy (supervised exercise) and standard management for patients awaiting knee replacement. Rheumatology 2007; 46: 14459.

[17] Murphy SL, Srasburg DM, Lyden AK, et al. Effects of activity strategy training on pain and physical activity in older adults with knee or hip osteoarthritis; a pilot study. Arthritis Rheum 2008; 59: 1480-7.

[18] Foley A, Halbert J, Hewitt T, Crotty M. Does hydrotherapy improve strength and physical function in patients with osteoarthritis: a randomized controlled trial comparing a gym based and a hydrotherapy based strengthening programme. Ann Rheum Dis 2003; 62: 1162-7.

[19] Fransen M, Nairn L, Winstanley J, Lam P, Edmonds J. Physical activity for osteoarthritis management: a randomized controlled clinical trial evaluating hydrotherapy or tai chi classes. Arthritis Rheum 2007; 57: 407-14.

[20] Gill SD, Mcburney H, Schulz DL. Land-based versus pool-based exercise for people awaiting joint replacement surgery of the hip or knee: results of a randomized controlled trial. Arch Phys Med Rehabil 2006; 90: 388-94.

[21] Arnold CM and Faulkner RA. The effect of aquatic exercise and education on lowering fall risk in older adults with hip osteoarthritis. J Aging Phys Activity 2010; 18: 245-60.

[22] Hale LA, Waters D, Herbison P. A randomized controlled trial to investigate the effects of water-based exercise to improve fall risks and physical function in older adults with lower-extremity osteoarthritis. Arch Phys Med Rehabil 2012; 93: 27-34.

[23] Messier SP, Loeser RF, Miller GD, et al. Exercise and dietary weight loss in overweight and obese older adults with knee osteoarthritis. Arthritis Rheum 2004; 50: 1501-10. 
[24] Miller GD, Nicklas BJ, Davis C, et al. Intensive weight loss program improves physical function in older obese adults with knee osteoarthritis. Obesity 2006; 14: 1219-30.

[25] Jadad RJ, Moore RA, Carroll D, et al. Assessing the quality of reports of randomized clinical trials: is blinding necessary? Controlled Clin Trials 1996; 17: 1-12.

[26] Fransen M, Mc McConnell S. Exercise for osteoarthritis of the knee (review). The Cochrane Collaboration, 2009; (3).

[27] Hurley MV. The role of muscle weakness in the pathogenesis of osteoarthritis. Rheum Dis Clin North Am 1999; 25: 283-98.

[28] Minor MA, Hewett JE, Webel RR, Anderson SK, Kay DR. Efficacy of physical conditioning exercise in patients with rheumatoid arthritis and osteoarthritis. Arthritis Rheum1989; 32: 1396-405.

[29] Miyaguchi M, Kobayashi A, Kadoya Y, et al. Biochemical change in joint fluid after isometric quadriceps exercise for patients with osteoarthritis of the knee. Osteoarthritis Cartilage 2003; 11: 252-9.

[30] Brosseau L, Pelland L, Wells G, et al. Efficacy of aerobic exercises for osteoarthritis (part II): a meta-analysis. Physical Therapy Reviews 2004; 9: 125-45.

[31] Pelland L, Brosseau L, Wells G, et al. Efficacy of strengthening exercises for osteoarthritis (part I): a meta-analysis. Physical Therapy Rev 2004; 9: 77-108.
[32] Lange AK, Vanwanseele B, Fiatarone Singh M. Strength training for treatment of osteoarthritis of the knee: a systematic review. Arthritis Care Res 2008; 59: 1488-94.

[33] Foy CG, Lewis CE, Hairston KG, et al. Intensive lifestyle intervention improves physical function among obese adults with knee pain: findings from the look AHEAD trial. Obesity 2011; 19: 83-93.

[34] Villareal DT, Apovian CM, Kushner RF, Klein S. Obesity in older adults: technical review and position statement of the American Society for Nutrition and NAASO. Obes Res 2005; 13: 1849-63.

[35] Shea MK, Houston DK, Nicklas BJ, et al. The effect of randomization to weight loss on total mortality in older overweight and obese adults: the ADAPT study. J Gerontol A Biol Sci Med Sci 2010; 65A: 519-25.

[36] Ashworth NI, Chad KE, Harrison EL, Reeder BA, Marshall SC. Home versus center based physical activity programs in older adults. The Cochrane Collaboration 2009; (1).

[37] Pfisters MF, Veenhof C, van Meeteren NLU, et al. Long-term effectiveness of exercise therapy in patients with osteoarthritis of the hip or knee: a systematic review. Arthritis Rheum 2007; 57: 1245-53.

[38] Crocker T, Forster A, Young J, et al. Physical rehabilitation for older people in long-term care (review). The Cochrane Collaboration 2013; (2)

(C) Le Quintrec et al.; Licensee Bentham Open.

This is an open access article licensed under the terms of the Creative Commons Attribution Non-Commercial License (http://creativecommons.org/licenses/by-nc/ 3.0/) which permits unrestricted, non-commercial use, distribution and reproduction in any medium, provided the work is properly cited. 